\title{
Mechanism and Optimized Process Conditions of Forming One- Dimensional ZnO Nanorods with Al-Doping by Electrodeposition Method
}

\author{
Jianlin Chen $\mathbb{D}^{1,2}$ Yu Zhang, ${ }^{1,2}$ Wei Qiu,, ${ }^{1,2}$ Shu Chen, ${ }^{1,2}$ Chang Liu, ${ }^{1,2}$ Zhuoyin Peng, ${ }^{1,2}$ \\ and Jian Chen $\left(^{1,2}\right.$ \\ ${ }^{1}$ School of Energy and Power Engineering, Changsha University of Science \& Technology, Hunan 410114, China \\ ${ }^{2}$ Key Laboratory of Energy Efficiency and Clean Utilization, Education Department of Hunan Province, Changsha University of \\ Science \& Technology, Hunan 410114, China \\ Correspondence should be addressed to Jian Chen; chenjian_513@126.com
}

Received 27 September 2020; Revised 20 January 2021; Accepted 21 February 2021; Published 16 March 2021

Academic Editor: Zaiyong Jiang

Copyright (C) 2021 Jianlin Chen et al. This is an open access article distributed under the Creative Commons Attribution License, which permits unrestricted use, distribution, and reproduction in any medium, provided the original work is properly cited.

\begin{abstract}
Textured transparent conductive electrodes for thin-film solar cells have been considered as an effective route for enhancing sunlight harvest due to light trapping. Here, we report a self-assembling electrochemical approach for preparing Al-doped $\mathrm{ZnO}$ nanorod arrays (NRAs) as light-trapping electrodes from a mixed aqueous solution of zinc nitrate and aluminium nitrate. The mechanism and optimized process conditions of forming one-dimensional $\mathrm{ZnO}$ nanorods with Al-doping were systematically investigated. The results showed that $\mathrm{Al}$ atoms were successfully doped into $\mathrm{ZnO}$ crystal lattice, and the morphologies could be controlled by adjusting the $\mathrm{Al}^{3+} / \mathrm{Zn}^{2+}$ ratio in the precursors and deposition time. The Al-doped $\mathrm{ZnO}$ films grew into wellaligned hexagonal NRAs with $c$-axis perpendicular to the substrates and then transited into a mixture of nanosheets and nanorods with $\mathrm{Al}^{3+} / \mathrm{Zn}^{2+}$ ratio increasing. They exhibited good electrical conductivity with a sheet resistance of $68-167 \Omega / s q u a r e$ and appropriate visible light transmittance of $61-82 \%$. Taking into account of desired morphology and phase purity, as well as good electrical conductivity and optical transmittance, the optimal window of $\mathrm{Al}^{3+} / \mathrm{Zn}^{2+}$ ratio in the precursors was determined between $1 \mathrm{at} \%$ and 2 at $\%$ with applied potential of $-1.5 \mathrm{~V}$, bath temperature of $80^{\circ} \mathrm{C}$, and deposition time of about $30 \mathrm{~min}$. The electrodeposition method provides a facile and efficient route for obtaining large-area textured transparent electrodes at a low cost.
\end{abstract}

\section{Introduction}

The hexagonal wurtzite zinc oxide $(\mathrm{ZnO})$ is a direct wide band gap semiconductor $(\sim 3.37 \mathrm{eV})$ with a relatively high exciton binding energy $(\sim 60 \mathrm{meV})$ at room temperature [1]. Due to its many excellent characteristics, it promises diverse applications, such as short-wavelength light-emitting diodes and lasing devices [2], transparent conductive oxide (TCO) films [3], piezoelectric transducers [4, 5], ultraviolet photodetectors [6], diluted magnetic semiconductors [7], gas sensors $[8,9]$, dye-sensitized solar cells [10-14], organic and polymer solar cell's electron transport layers $[15,16]$, photo- catalytic degradation and hydrogen production [17-24]. Also, n-type doped (e.g., Al, Ga, or In-doped) $\mathrm{ZnO}$ films have been extensively used as transparent electrodes of thin-film solar cells due to their superior advantages, such as high optical transparency, excellent electrical conductivity, high stability in hydrogen plasma atmosphere, nontoxicity, inexpensive and abundant raw materials, and diversity of fabrication methods $[25,26]$. $\mathrm{ZnO}$ has also attracted great interest due to its unique ability to form a variety of onedimensional nanostructures [27]. Over the past decades, various methods have been developed to fabricate complex and oriented $\mathrm{ZnO}$ nanostructure arrays, including chemical 
vapor deposition, vapor-liquid-solid, sol-gel, hydrothermal, spray pyrolysis, and electrodeposition methods. In comparison with other methods, the electrodeposition method represents a facile route for synthesizing a well-aligned $\mathrm{ZnO}$ nanowire [28, 29], nanorod [30], or nanotube arrays [31] on transparent conductive oxide substrates. It is convenient to tune the crystal shape, diameter, length, aspect ratio, morphology, orientation, and distribution by adjusting the growth parameters including applied potential, ion concentration, $\mathrm{pH}$ value, temperature, deposition time, seeded substrates, and active agents [32-34]. So far, intrinsic $\mathrm{ZnO}$ one-dimensional nanostructures have been intensively studied for light-trapping or electron transport structures for diverse solar cells [35-44]. On the contrary, there are very few studies focusing on foreign atom being doped into $\mathrm{ZnO}$ nanostructures via the electrosynthesis process $[45,46]$.

However, the electrical conductivity of intrinsic $\mathrm{ZnO}$ nanostructures is limited due to low carrier concentration, which will greatly increase the series resistance of solar cells to degrade the photovoltaic performance. It is well known that the group III atoms, such as $\mathrm{B}, \mathrm{Al}, \mathrm{Ga}$, and In, being doped into $\mathrm{ZnO}$ can greatly increase the carrier concentration and thus the conductivity, which is related to the contribution from group III atom substituting $\mathrm{Zn}$ site leading to one extra free electron. Also, previous studies have shown that the electron transport velocity along the c-axis of onedimensional $\mathrm{ZnO}$ crystals was several orders of magnitude faster than that of randomly preferred crystalline $\mathrm{ZnO}$ particles [10]. Both of these may enhance the conductivity of group III-doped well-aligned $\mathrm{ZnO}$ nanorod arrays (NRAs). In addition, the size of $\mathrm{ZnO}$ nanorods is comparable to the visible light wavelengths of the solar spectrum, which facilitates their unique light scattering and capturing effects. In view of these factors, transparent conductive group IIIdoped $\mathrm{ZnO}$ NRAs may be used as transparent electrodes for thin film-based solar cells, such as a-Si, dye-sensitized or quantum dot-sensitized, copper indium gallium selenide (CIGS), and perovskite solar cells. The one-dimensional nanostructures with proper geometrical configuration not only can trap photons more effectively but also facilitate collecting the photo-induced electrons, both of these leading to enhancement of power conversion efficiency. Furthermore, the increasing contacting area between transparent conductive $\mathrm{ZnO}$ NRA electrodes and active layers of thin-film solar cells will do benefit to collecting photo-induced electrons more efficiently and quickly, reducing charge accumulation at the interfaces. Nevertheless, the approaches of doping group III atoms into one-dimensional $\mathrm{ZnO}$ single crystallize arrays at large-area and low cost still remain a significant challenge. The mechanism of doped $\mathrm{ZnO}$ nanostructures from a zinc nitrate aqueous solution with doping ions has not been thoroughly clarified, which is vital for well tuning the morphology and foreign atoms being effectively doped into $\mathrm{ZnO}$ lattice.

In this work, in order to obtain transparent conductive $\mathrm{ZnO}$ with light-trapping effect, the electrosynthesis mechanism and process of Al-doped $\mathrm{ZnO}$ NRAs on fluorinedoped tin oxide (FTO) glass substrates from a mixed aqueous solution of zinc nitrate and aluminium nitrate with different $\mathrm{Al}^{3+} / \mathrm{Zn}^{2+}$ ratio were systematically investigated.

\section{Materials and Methods}

Zinc nitrate hexahydrate $\left[\mathrm{Zn}\left(\mathrm{NO}_{3}\right)_{2} \bullet 6 \mathrm{H}_{2} \mathrm{O}\right]$ and aluminium nitrate nonahydrate $\left[\mathrm{Al}\left(\mathrm{NO}_{3}\right)_{3} \bullet 9 \mathrm{H}_{2} \mathrm{O}\right]$ with analytical reagent grade were the starting materials of $\mathrm{Zn}$ and $\mathrm{Al}$, respectively. The samples were grown by electrodeposition method from zinc nitrate and aluminium nitrate mixed aqueous solutions without other auxiliary reagents on FTO film glass substrates with a sheet resistance of $15-18 \Omega /$ sq at an applied potential of $-1.5 \mathrm{~V}$. All electrodepositions were carried out potentiostatically at $80^{\circ} \mathrm{C}$ in a two-electrode system with a FTO conductive glass piece as the workingelectrode and a platinum-titanium composite mesh as the counter electrode. The distance between the working electrode and the counter electrode was kept $2 \mathrm{~cm}$. The concentration of zinc nitrate in the solutions was $3 \mathrm{mmol} / \mathrm{L}$, and the amount of aluminium nitrate nonahydrate was added according to different $\mathrm{Al}^{3+} / \mathrm{Zn}^{2+}$ ratio of $0,1,2$, and 3 at $\%$ in the precursors. Prior to each electrodeposition run, the FTO substrates were ultrasonically cleaned in acetone and ethanol for $30 \mathrm{~min}$ in each solvent, respectively. At the end of the growth period, the FTO substrates covered with $\mathrm{ZnO}$ were removed from the solution and immediately rinsed in flowing deionized water to eliminate any residual impurities from the surface. Finally, the samples were thermally treated at $530^{\circ} \mathrm{C}$ in air for $1 \mathrm{~h}$ and $420^{\circ} \mathrm{C}$ in a vacuum for $30 \mathrm{~min}$ in sequence.

The crystallographic characterization was investigated by an X-ray diffractometer (XRD, D/Max-rA, Japan). The micrograph and chemical composition were observed by field emission scanning electron micrographs (FESEM, JSM-6700F, Japan) with an energy dispersive X-ray spectrometer (EDS). Transmission electron microscopy (TEM) images were obtained on a microscope (Tecnai G ${ }^{2}$ F20 STWIN, USA) with an accelerating voltage of $200 \mathrm{kV}$. The $\mathrm{X}$-ray photoelectron spectroscopy (XPS) measurement was performed to confirm the element status of samples on an ultrahigh-vacuum electron spectrometer (VG ESCALAB 250Xi, USA). The sheet resistance was measured by an M-3 four-probe tester (Suzhou Jingge Electronic Co. Ltd, China). The cyclic voltammogram spectrum test was carried out using a German Zahner electrochemical workstation.

\section{Results and Discussion}

3.1. Reaction and Growth Mechanism. As many previous reports depicted, a fundamental reaction in electrodepositing $\mathrm{ZnO}$ from the $\mathrm{Zn}\left(\mathrm{NO}_{3}\right)_{2}$ aqueous solutions is based on the reduction of nitrate ions into nitrite ions with $\mathrm{OH}^{-}$ ions generating [47]. The $\mathrm{ZnO}$ formation is not a simple faradaic process but an electrochemically induced precipitation process. The local $\mathrm{OH}^{-}$ion concentration increase will lead to the reversible precipitating reaction of $\mathrm{OH}^{-}$ and $\mathrm{Zn}^{2+}$ ions. Then, the formed $\mathrm{Zn}(\mathrm{OH})_{2}$ is transformed into $\mathrm{ZnO}$ at elevated temperature. If there are some $\mathrm{Al}^{3+}$ ions also existing in the solutions, similar reactions may 


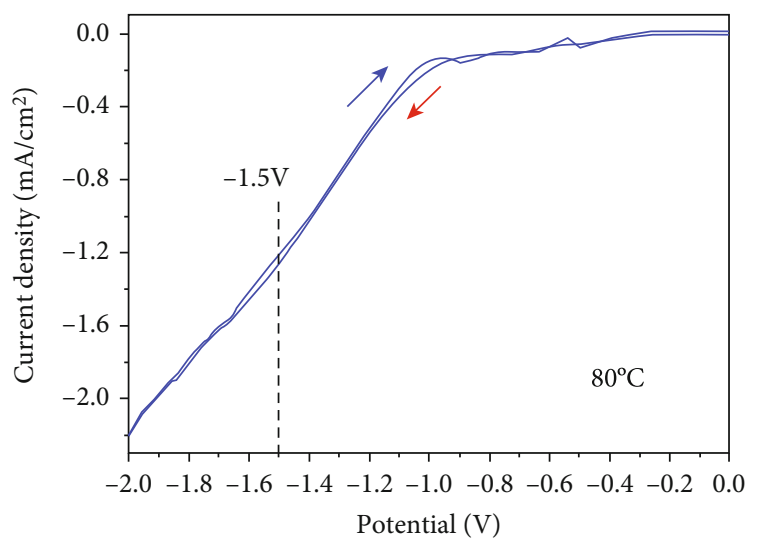

(a)

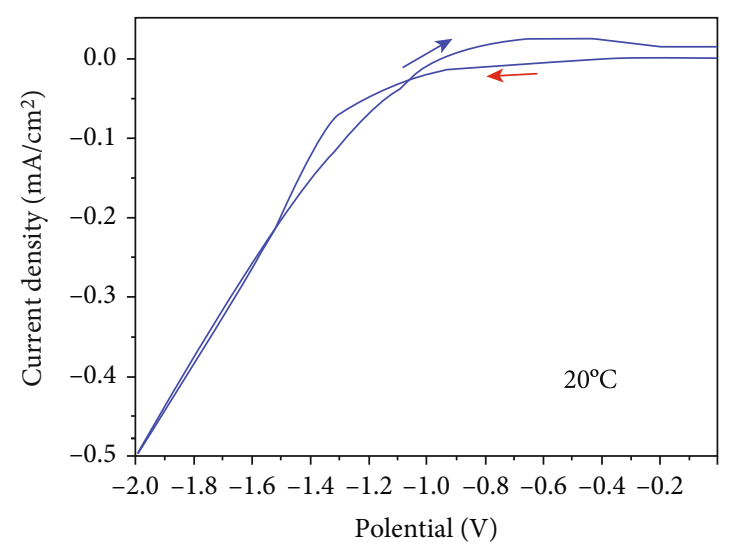

(b)

Figure 1: Cyclic voltammogram of the $3 \mathrm{mM} \mathrm{Zn}\left(\mathrm{NO}_{3}\right)_{2}$ aqueous solutions on FTO-coated glass with the working and counter electrode distance $2 \mathrm{~cm}$ and the scan rate $30 \mathrm{mV} / \mathrm{s}$ at (a) $80^{\circ} \mathrm{C}$ and (b) $20^{\circ} \mathrm{C}$.

occur. The doping mechanism is believed to be coprecipitation of $\mathrm{Zn}(\mathrm{OH})_{2}$ with $\mathrm{Al}^{3+}$ substituting $\mathrm{Zn}^{2+}$ sites [48]. The reactions can be generally listed as follows:

$$
\begin{aligned}
\mathrm{NO}_{3}^{-}+\mathrm{H}_{2} \mathrm{O}+2 \mathrm{e}^{-} & \longrightarrow \mathrm{NO}_{2}^{-}+2 \mathrm{OH}^{-}, \\
\mathrm{Zn}^{2+}+2 \mathrm{OH}^{-} & \longleftrightarrow \mathrm{Zn}(\mathrm{OH})_{2} \downarrow \\
\mathrm{Al}^{3+}+3 \mathrm{OH}^{-} & \longleftrightarrow \mathrm{Al}(\mathrm{OH})_{3} \downarrow \\
\mathrm{Zn}(\mathrm{OH})_{2} & \longrightarrow \mathrm{ZnO}+\mathrm{H}_{2} \mathrm{O}, \\
2 \mathrm{Al}(\mathrm{OH})_{3} & \longrightarrow \mathrm{Al}_{2} \mathrm{O}_{3}+3 \mathrm{H}_{2} \mathrm{O} .
\end{aligned}
$$

The forms of final products strongly depend on the depositing parameters including the $\mathrm{Zn}^{2+}$ ion concentration, applied potential, $\mathrm{pH}$ value, temperature, deposition time, distance between electrodes, and active agents. $\mathrm{ZnO}$ may be electrodeposited in the form of compact films, hexagonal plates, rods, wires, and even tubes as discussed in literature [28-31]. Supposing the precipitating reaction is controlled at a moderate rate, i.e., when the $\mathrm{Zn}^{2+}$ or $\mathrm{OH}^{-}$ion concentrations in the solutions are very low, one-dimensional hexagonal $\mathrm{ZnO}$ nanostructure arrays may be formed by controlling the nucleation and growth process.

In order to choose a suitable applied potential and depositing temperature for growing $\mathrm{ZnO}$ NRAs, cyclic voltammetry (CV) was carried out for the aqueous solution of $3 \mathrm{mM} \mathrm{Zn}\left(\mathrm{NO}_{3}\right)_{2}$. Figure 1 shows the cyclic voltammogram of the FTO-electrolyte interface recorded upon a first voltammetry scan with the working and counter electrode distance of $2 \mathrm{~cm}$ at $20^{\circ} \mathrm{C}$ and $80^{\circ} \mathrm{C}$, respectively. As for the deposition temperature of $80^{\circ} \mathrm{C}$ (Figure $1(\mathrm{a})$ ), no significant current can be observed at the potential ranging from 0 to $-0.8 \mathrm{~V}$, which suggests that no electrochemical reactions occur before the applied potential increases to $-0.8 \mathrm{~V}$. A cathodic current starts to increase at about $-0.8 \mathrm{~V}$, which can be assigned to the reduction of nitrate ions to nitrite ions. As the applied potential is increased negatively, the cathodic current arises due to the increased rate of the nitrate reduction reaction. Between the applied potentials from $-0.8 \mathrm{~V}$ to $-2.0 \mathrm{~V}$, there is no obvious other peak current appearing, which proves that no $\mathrm{Zn}^{2+}$ ions were reduced to metallic zinc. Kemell et al. [46] had electrodeposited potentiostatically $\mathrm{ZnO}$ thin films doped with $\mathrm{Al}$ at $80^{\circ} \mathrm{C}$ from $50 \mathrm{mM} \mathrm{Zn}\left(\mathrm{NO}_{3}\right)_{2}$ aqueous solutions containing $1-10 \mathrm{mM}$ $\mathrm{Al}\left(\mathrm{NO}_{3}\right)_{3}$. They found that at more negative potentials, the amount of $\mathrm{Al}$ decreased and that of $\mathrm{Zn}$ increased, which could be attributed to the electrochemically generated hydroxide ions reacting more thermodynamically easily with $\mathrm{Al}^{3+}$ ions than with $\mathrm{Zn}^{2+}$ ions; when the applied potentials between -1.0 and $-1.6 \mathrm{~V}$, the resulted $\mathrm{Al}$ concentration in the $\mathrm{ZnO}$ films was $2-8$ at $\%$.

Generally, a more nonequilibrium growth environment favours for $\mathrm{Al}^{3+}$ ions being in situ doped into $\mathrm{ZnO}$ lattice via solution chemical routes. Clearly, high $\mathrm{Zn}^{2+}$ concentration and applied potential are more favourable for such a nonequilibrium environment. However, in terms of thermodynamics, it may be a contradiction between the growth of one-dimensional single-crystalline $\mathrm{ZnO}$ and foreign atoms being doped into $\mathrm{ZnO}$. It may be easy to prepare doped $\mathrm{ZnO}$ dense films by electrodeposition method, while this is not necessarily suitable for the growth of one-dimensional crystalline doped $\mathrm{ZnO}$ nanostructures. In this work, a relatively high applied potential of $-1.5 \mathrm{~V}$, which is aiming at a more nonequilibrium growth environment for $\mathrm{Al}^{3+}$ ions entering into $\mathrm{ZnO}$ crystal lattice, is chosen for electrochemically growing $\mathrm{Al}$-doped $\mathrm{ZnO}$ NRAs. Thereby, the local $\mathrm{OH}^{-}$ concentration near the cathode is relatively high at this applied potential but keeping $\mathrm{Zn}^{2+}$ concentration low in the overall solution.

As for the deposition temperature, there appears an anodic peak begins at about $-0.9 \mathrm{~V}$ when sweeping back the potential for $20^{\circ} \mathrm{C}$ (Figure 1(b)). It corresponds to the oxidation of the previously deposited metallic Zn, which is consistent with the results of Liang et al. [47]. In comparison, there is no anodic peak detected for $80^{\circ} \mathrm{C}$. It may be attributed to the faster consumption of $\mathrm{Zn}^{2+}$ ion being precipitated into $\mathrm{Zn}(\mathrm{OH})_{2}$ and thus no more $\mathrm{Zn}^{2+}$ ions being reduced into metal zinc at relatively high temperature. In addition, it can be seen that the current density at $80^{\circ} \mathrm{C}$ is remarkably larger 


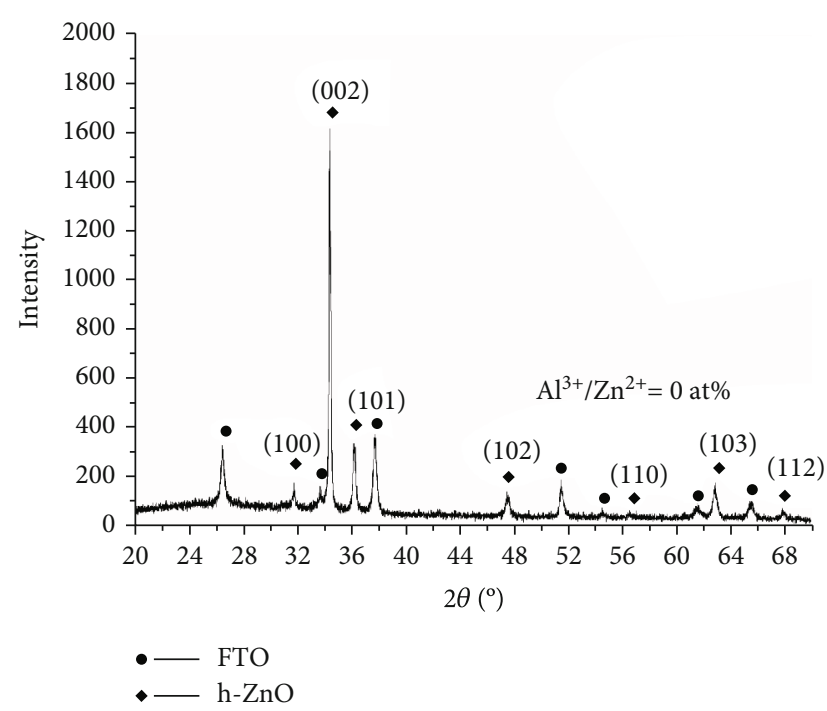

(a)

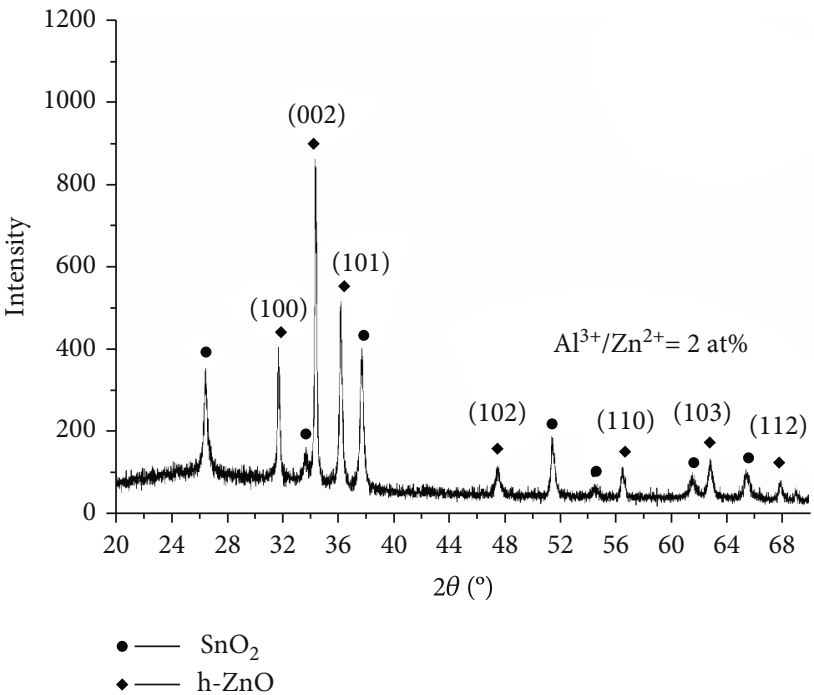

(c)

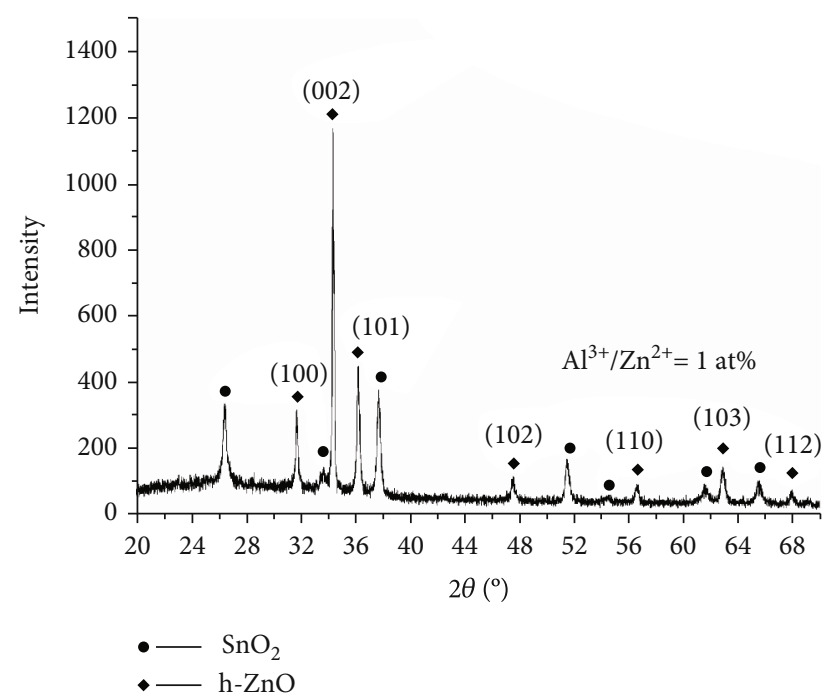

(b)

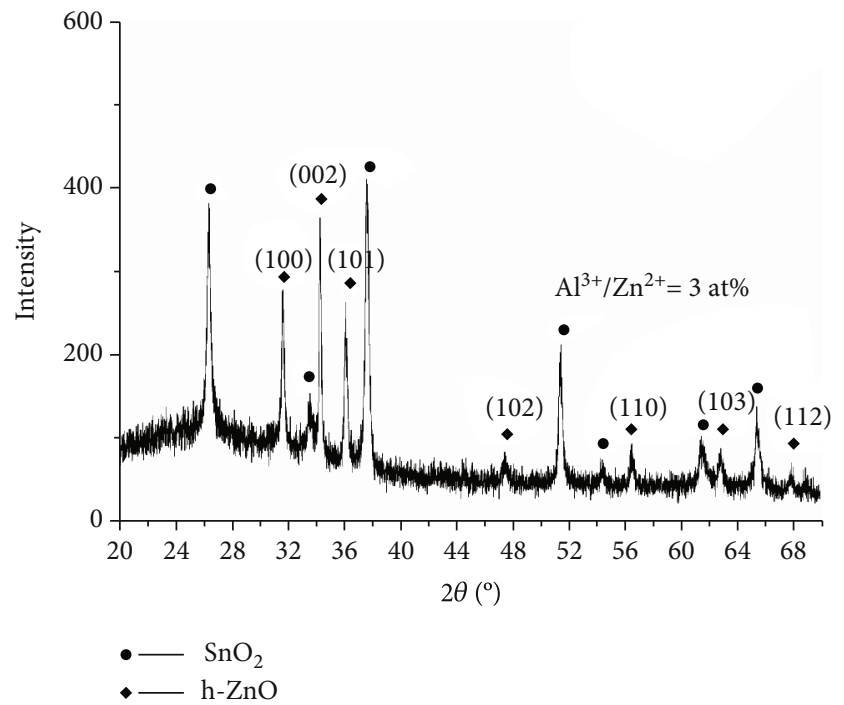

(d)

Figure 2: X-ray diffraction patterns of the $\mathrm{ZnO}$ samples formed on FTO substrates by electrodeposition method at a constant potential -1.5 V from $3 \mathrm{mM} \mathrm{Zn}\left(\mathrm{NO}_{3}\right)_{2}$ aqueous solutions containing $\mathrm{Al}\left(\mathrm{NO}_{3}\right)_{3}$ with different $\mathrm{Al}^{3+} / \mathrm{Zn}^{2+}$ ratio in the bath: (a) 0 at $\%$, (b) 1 at $\%$, (c) 2 at $\%$, and (d) 3 at $\%$, at $80^{\circ} \mathrm{C}$ for $60 \mathrm{~min}$ with a fixed electrode distance of $2 \mathrm{~cm}$.

TABle 1: Position and intensity of the characteristic peaks of $\mathrm{ZnO}$ samples in Figure 2.

\begin{tabular}{lccccc}
\hline $\mathrm{Al}^{3+} / \mathrm{Zn}^{2+}($ at\% $)$ & $2 \theta(002)$ & $I(100)$ & $I(002)$ & $I(101)$ & $i(002)$ \\
\hline 0 & $34.4835^{\circ}$ & 182 & 1623 & 344 & 0.7552 \\
1 & $34.4579^{\circ}$ & 316 & 1169 & 453 & 0.6032 \\
2 & $34.4494^{\circ}$ & 405 & 863 & 518 & 0.4832 \\
3 & $34.3984^{\circ}$ & 280 & 366 & 265 & 0.4018 \\
\hline
\end{tabular}

than that at $20^{\circ} \mathrm{C}$ at the same applied potentials, which can be assigned to the accelerating of ion migration and reaction rate at higher temperature. On the other hand, the formed $\mathrm{Zn}(\mathrm{OH})_{2}$ can be transformed into $\mathrm{ZnO}$ only at elevated temperature.
3.2. Structure and Morphology with $\mathrm{Al}^{3+} / \mathrm{Zn}^{2+}$ Ratio in the Precursors. Figure 2 shows X-ray diffraction patterns of the $\mathrm{ZnO}$ samples electrodeposited on FTO substrates from $3 \mathrm{mM} \mathrm{Zn}\left(\mathrm{NO}_{3}\right)_{2}$ aqueous solutions containing $\mathrm{Al}\left(\mathrm{NO}_{3}\right)_{3}$ with different $\mathrm{Al}^{3+} / \mathrm{Zn}^{2+}$ ratio. It can be seen that all the samples exhibit the characteristic peaks of hexagonal wurtzite $\mathrm{ZnO}$ excluding the peaks of polycrystalline tetragonal $\mathrm{SnO}_{2}$ from the FTO substrates, with no additional peaks corresponding to alumina or other phases. The diffraction peaks of $2 \theta=31.77^{\circ}, 34.42^{\circ}, 36.25^{\circ}, 47.54^{\circ}, 56.60^{\circ}, 62.86^{\circ}$, and $67.96^{\circ}$ can be assigned to (100), (002), (101), (102), (110), (103), (112), and (004) planes of hexagonal $\mathrm{ZnO}$. Moreover, the intensity of (002) peak is obviously stronger than that of other peaks, which indicates that the preferred orientation growth along the $\mathrm{c}$-axis perpendicular to the substrates. However, the diffracting peaks of (002) plane become weaker 


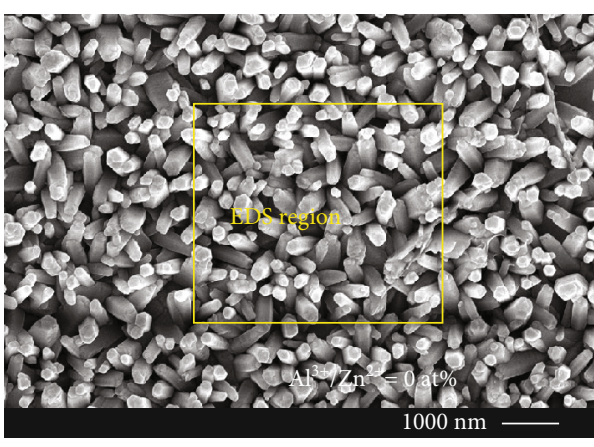

(a)

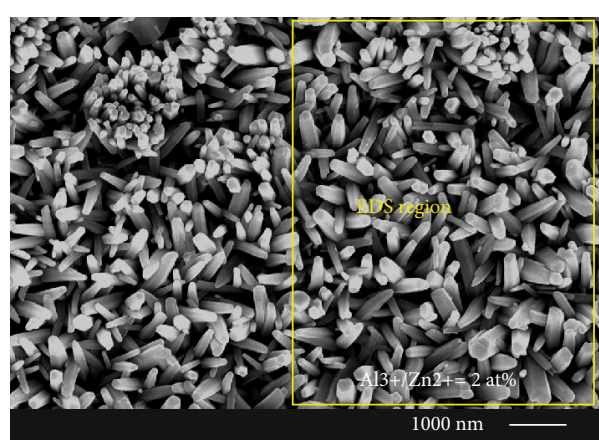

(c)

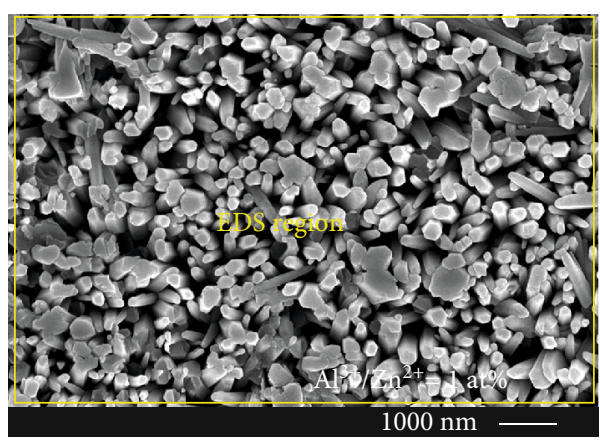

(b)

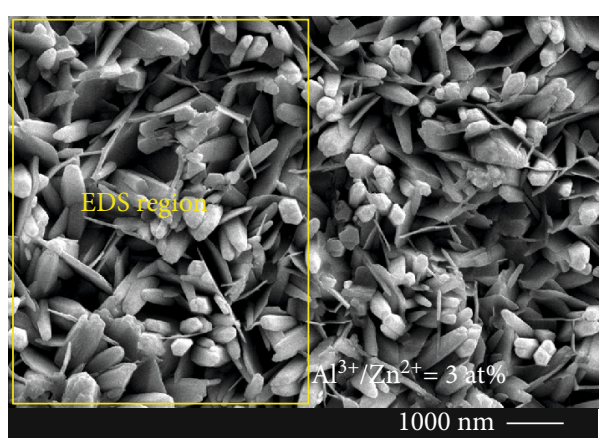

(d)

FIGURE 3: SEM images of $\mathrm{ZnO}$ films formed on FTO substrates by electrodeposition method at a constant potential $-1.5 \mathrm{~V}$ from $3 \mathrm{mM}$ $\mathrm{Zn}\left(\mathrm{NO}_{3}\right)_{2}$ aqueous solutions containing $\mathrm{Al}\left(\mathrm{NO}_{3}\right)_{3}$ with different $\mathrm{Al}^{3+} / \mathrm{Zn}^{2+}$ ratio in the bath: (a) 0 at $\%$, (b) 1 at $\%$, (c) 2 at $\%$, and (d) 3 at $\%$, at $80^{\circ} \mathrm{C}$ for $60 \mathrm{~min}$ with a fixed electrode distance $2 \mathrm{~cm}$.

with the $\mathrm{Al}^{3+} / \mathrm{Zn}^{2+}$ ratio increasing, and the pure $\mathrm{ZnO}$ sample exhibits the most strongest. As for the sample with an $\mathrm{Al}^{3+} / \mathrm{Zn}^{2+}$ ratio of 3 at $\%$, it shows no preferred orientation of (002) plane. The (002) preferred orientation growth of $\mathrm{ZnO}$ crystals can be also characterized using the relative intensity of (002) plane, which is defined as formula (6) and calculated as shown in Table 1.

$$
i(002)=I(002) /[I(100)+I(002)+I(101)]
$$

in which i(002), $I(100), I(002)$, and $I(101)$ are representing the relative intensity of (002) plane and the intensity of (100), (002), and (101) plane, respectively.

It is obvious that the diffracting intensity becomes weaker with the $\mathrm{Al}^{3+} / \mathrm{Zn}^{2+}$ ratio increasing, which indicates that the existence of $\mathrm{Al}^{3+}$ ions in the solutions may affect the depositing and crystallizing process and decrease the crystallinity and preferred orientation growth. It may be attributed to the formation of stress-induced by ion size difference between $\mathrm{Zn}^{2+}$ and $\mathrm{Al}^{3+}$ ions or the segregation of amorphous alumina in grain boundaries [48]. Besides, it is worth noting that the position of (002) peak shifts to a lower angle with the $\mathrm{Al}^{3+} / \mathrm{Zn}^{2+}$ ratio increasing, which can be attributed to the lattice strain originating from Al-doping; conversely, it confirms that $\mathrm{Al}$ atoms are successfully doped into $\mathrm{ZnO}$ lattice.

Figure 3 exhibits morphologies of the same $\mathrm{ZnO}$ samples with different $\mathrm{Al}^{3+} / \mathrm{Zn}^{2+}$ ratio. It can be seen that well-aligned hexagonal $\mathrm{ZnO}$ NRAs were grown with the $\mathrm{c}$-axis perpendicular to the substrates except the sample with the $\mathrm{Al}^{3+} / \mathrm{Zn}^{2+}$ ratio of 3 at $\%$. There is little difference in the shape, size, and orientation of nanorod arrays for the samples with the $\mathrm{Al}^{3+} / \mathrm{Zn}^{2+}$ ratios of 0 at\% (Figure 3(a)) and 1 at $\%$ (Figure 3(b)). The diameter of nanorods is in the range of $80-220 \mathrm{~nm}$. Compared to the former two, the diameter of nanorods for the sample with the $\mathrm{Al}^{3+} / \mathrm{Zn}^{2+}$ ratio of 2 at $\%$ (Figure 3(c)) clearly becomes smaller, which is in the range of $50-120 \mathrm{~nm}$, and its distribution is more uniform. From Figure 3(c) and 3(d), it is more worthy of attention that the deposited $\mathrm{Al}$-doped $\mathrm{ZnO}$ films grow into well-aligned hexagonal nanorod arrays with the c-axis perpendicular to the substrates and then transit to a mixture of nanosheets and nanorods.

Figure 4 shows the analysis of X-ray energy dispersive spectra (EDS) and elemental ratio for the samples corresponding to the SEM images in Figure 3, respectively. The $\mathrm{Sn}, \mathrm{Ca}$, and $\mathrm{Si}$ elements come from the FTO glass substrates. As for the sample with an $\mathrm{Al}^{3+} / \mathrm{Zn}^{2+}$ ratio of 0 at\%, there are no $\mathrm{Al}$ atoms detected while existing for other samples, which indicates that $\mathrm{Al}$ atoms have been successfully deposited with $\mathrm{Zn}$ atoms for the $\mathrm{Zn}\left(\mathrm{NO}_{3}\right)_{2}$ aqueous solution containing $\mathrm{Al}\left(\mathrm{NO}_{3}\right)_{3}$. It can be seen that the actually resulted $\mathrm{Al} / \mathrm{Zn}$ ratio in the samples increases with the $\mathrm{Al}^{3+} / \mathrm{Zn}^{2+}$ ratio in the precursor bath.

Transmission electron microscopy (TEM) was employed to further demonstrate the shape, size, phase, and element composition of the Al-doped $\mathrm{ZnO}$ sample with 1 at $\% \mathrm{Al}^{3+} /$ $\mathrm{Zn}^{2+}$ ratio in the precursor, as shown in Figure 5. From the TEM image in Figure 5(a), the diameter and length of the 


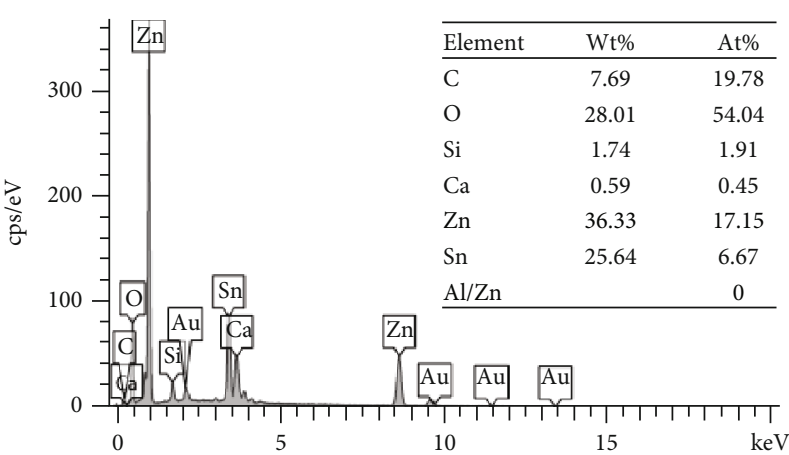

(a)

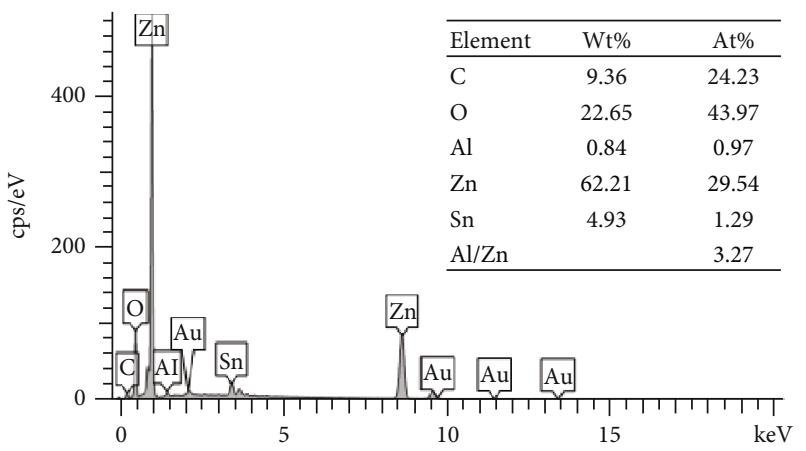

(c)

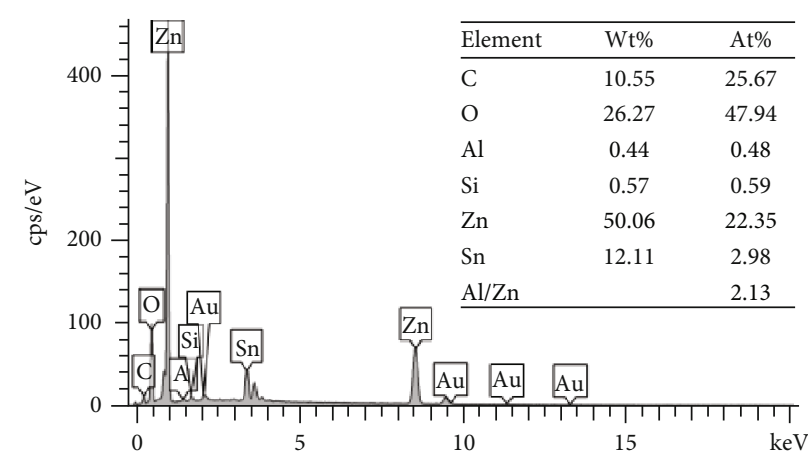

(b)

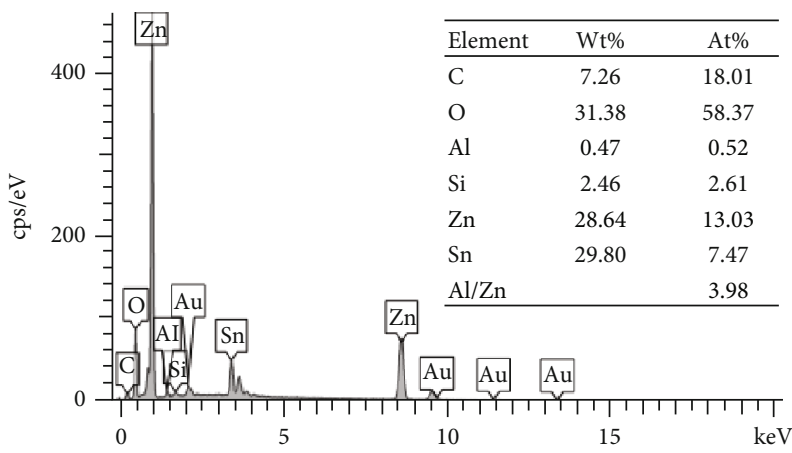

(d)

FIGURE 4: Energy dispersive analysis of X-ray spectra (EDS) for the $\mathrm{ZnO}$ samples corresponding to the SEM images in Figure 3.

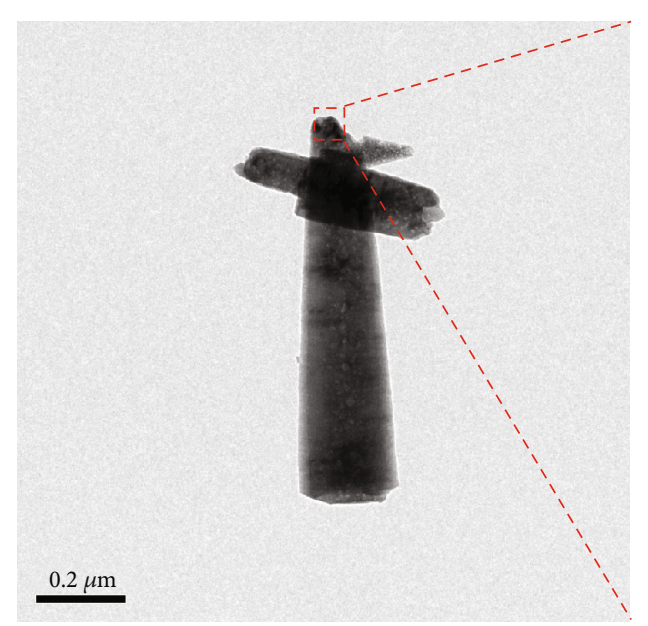

(a)

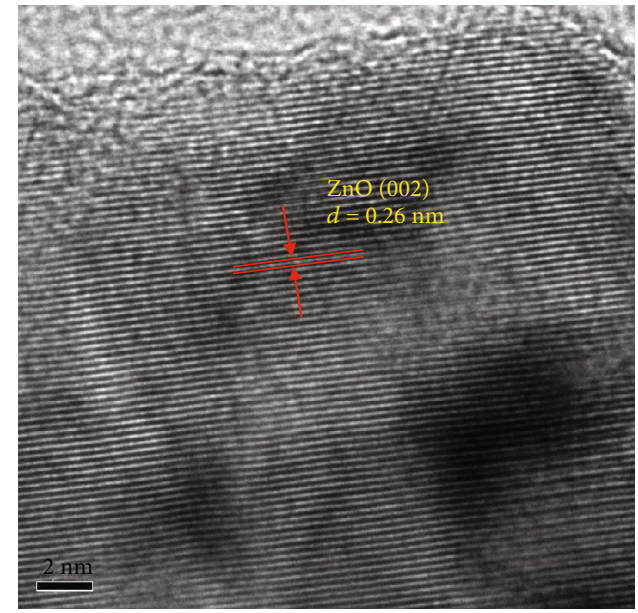

(b)
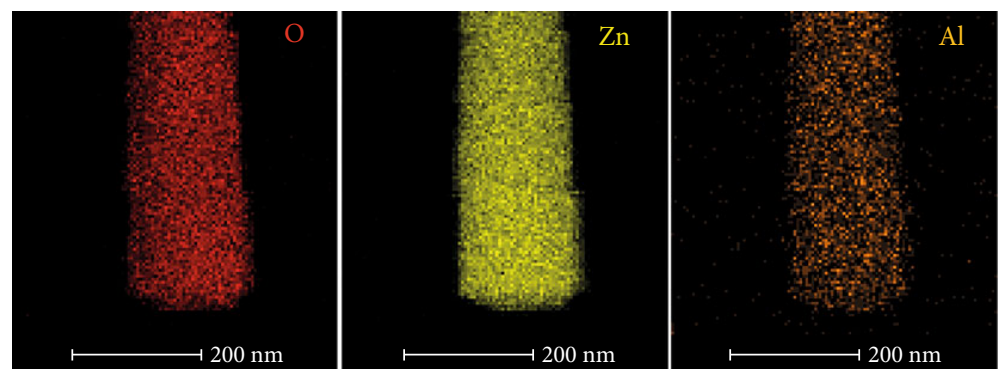

(c)

FIgURE 5: (a) TEM, (b) HRTEM, and (c) EDS elemental mapping images of the Al-doped $\mathrm{ZnO}$ sample with the $\mathrm{Al}^{3+} / \mathrm{Zn}^{2+}$ ratio of 1 at\% in the precursor bath. 


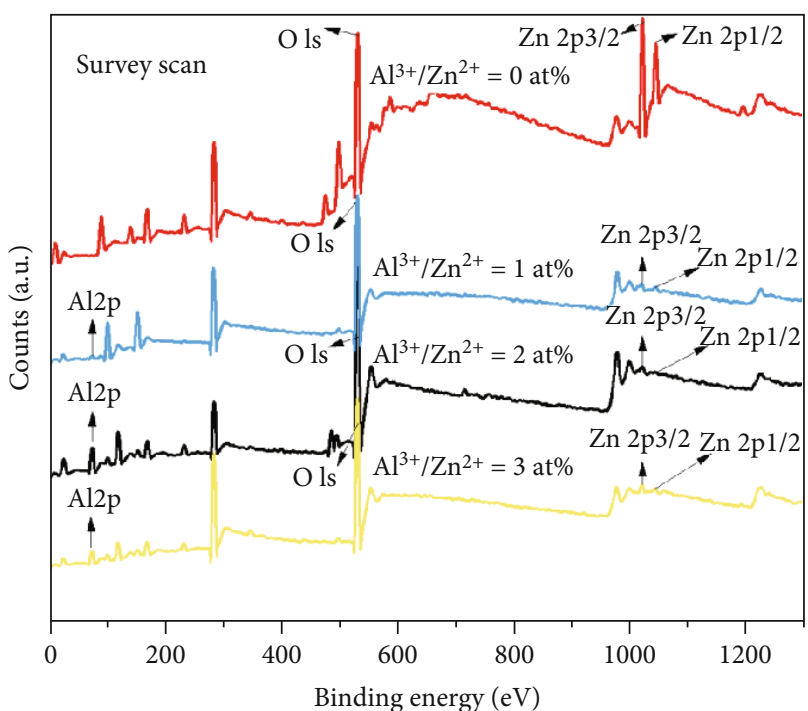

(a)

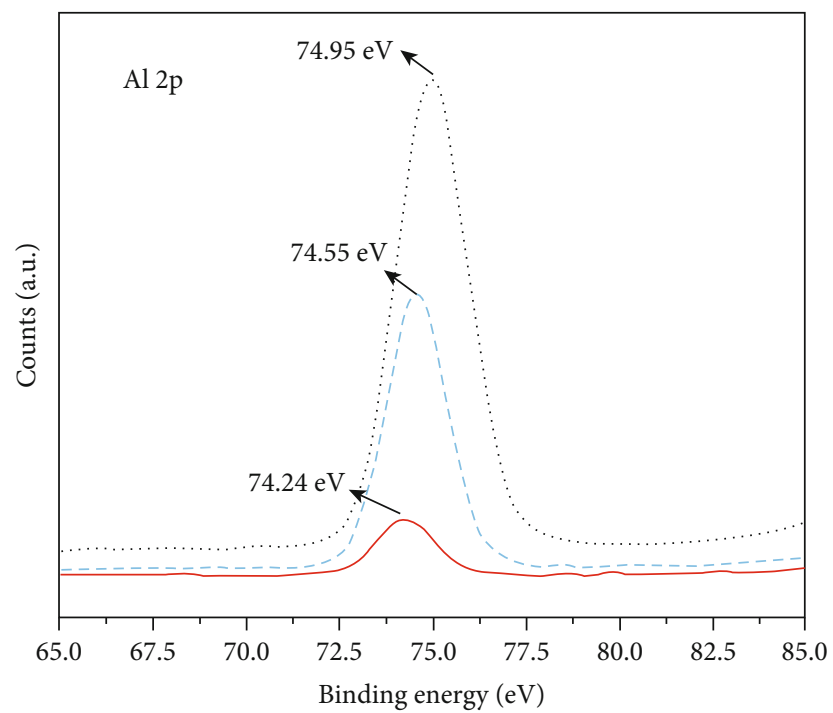

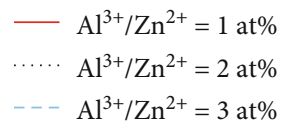

(b)

Figure 6: XPS spectra of (a) survey scan and (b) $\mathrm{Al} 2 \mathrm{p}$ peaks of the $\mathrm{ZnO}$ samples with different $\mathrm{Al}^{3+} / \mathrm{Zn}^{2+}$ ratio in the precursors.

nanorod is $200 \mathrm{~nm}$ and $850 \mathrm{~nm}$ or so, respectively, which is consistent with those seen from SEM images in Figure 3(b). As zoomed in the square area by high-resolution TEM image of Figure 5(b), the lattice fringes of nanorod are estimated at $0.26 \mathrm{~nm}$, which can be assigned as the (002) plane of hexagonal $\mathrm{ZnO}$, which confirms that the nanorod is hexagonal wurtzite $\mathrm{ZnO}$ single crystal. In addition, as seen from the EDS elemental mapping images of the nanorod in Figure 5(c), the Al element is uniformly distributed throughout the nanorod, and the amount of $\mathrm{Al}$ element is obviously lower than that of the $\mathrm{Zn}$ element.

XPS was adopted to characterize the element composition and chemical bonding state of the pure and Al-doped $\mathrm{ZnO}$ samples. Figure 6(a) shows that the full-survey scan spectra exhibit clear peaks of $\mathrm{Zn}, \mathrm{O}$, and $\mathrm{Al}$ elements in all the $\mathrm{Al}$-doped $\mathrm{ZnO}$ samples, while no $\mathrm{Al}$ element is detected for the pure $\mathrm{ZnO}$ sample, further proving the presence of $\mathrm{Al}$ element in the $\mathrm{Al}$-doped $\mathrm{ZnO}$ samples. It should be pointed out that the intensity of the $\mathrm{Zn}$ element in the pure $\mathrm{ZnO}$ sample is greatly stronger than those in the Al-doped $\mathrm{ZnO}$ samples. The high-resolution $\mathrm{Al} 2 p$ peaks are shown in Figure 6(b), which locate at $74.24 \mathrm{eV}, 74.95 \mathrm{eV}$, and $74.55 \mathrm{eV}$ for the $\mathrm{Al}$-doped $\mathrm{ZnO}$ samples with $\mathrm{Al}^{3+} / \mathrm{Zn}^{2+}$ ratio of 1,2 , and 3 at $\%$ in the precursors, respectively. The binding energy firstly increases with $\mathrm{Al}^{3+} / \mathrm{Zn}^{2+}$ ratio from 1 at $\%$ to 2 at $\%$ and then decreases with $\mathrm{Al}^{3+} / \mathrm{Zn}^{2+}$ ratio rising up to 3 at\%, which may be attributed to some amorphous $\mathrm{Al}_{2} \mathrm{O}_{3}$ phase existing in the Al-doped $\mathrm{ZnO}$ sample with 3 at $\% \mathrm{Al}^{3+} /$ $\mathrm{Zn}^{2+}$ ratio.

3.3. Morphological Evolution with the Deposition Time. Figure 7 shows the morphological evolution of Al-doped
$\mathrm{ZnO}$ electrodeposited from $3 \mathrm{mM} \mathrm{Zn}\left(\mathrm{NO}_{3}\right)_{2}$ aqueous solution with $\mathrm{Al}^{3+} / \mathrm{Zn}^{2+}$ ratio of 1 at $\%$ as a function of depositing time. It can be clearly seen that with depositing time increasing $(10,30,60$, and $90 \mathrm{~min})$, the samples gradually grow from small irregular grains into hexagonal crystals. The hexagonal crystals obviously become more perfectly crystalline and larger with the diameter of $200-500 \mathrm{~nm}$ corresponding to the depositing time of $90 \mathrm{~min}$.

3.4. Electrical and Optical Properties. The sheet resistance of $\mathrm{ZnO}$ samples electrodeposited from $3 \mathrm{mM} \mathrm{Zn}\left(\mathrm{NO}_{3}\right)_{2}$ aqueous solutions containing $\mathrm{Al}\left(\mathrm{NO}_{3}\right)_{3}$ with $\mathrm{Al}^{3+} / \mathrm{Zn}^{2+}$ ratio of $0,1,2$, and 3 at $\%$ was measured by the four-point-probe method, which was $1856,167,95$, and $68 \Omega /$ sq, respectively. In our previous work, the sheet resistance of the sample with $\mathrm{Al}^{3+} / \mathrm{Zn}^{2+}$ ratio of 3.3 at $\%$ was $162 \Omega /$ sq [49]. Thus, the sheet resistance of pure and $\mathrm{Al}$-doped $\mathrm{ZnO}$ samples as a function of the $\mathrm{Al}^{3+} / \mathrm{Zn}^{2+}$ ratio in the precursors is shown in Figure 8. It is clearly shown that the electrical conductivity of $\mathrm{Al}$ doped $\mathrm{ZnO}$ samples is superior to that of pure $\mathrm{ZnO}$ sample, which is increased by almost two orders of magnitude. It also proves that $\mathrm{Al}$ atoms are effectively doped into $\mathrm{ZnO}$ lattice, which contributes to the enhancement of the electrical conductivity. As for the Al-doped $\mathrm{ZnO}$ samples, the conductivity is improved with the $\mathrm{Al}^{3+} / \mathrm{Zn}^{2+}$ ratio increasing. Of course, the electrical conductivity may be related to many factors including doping effect, crystallinity, crystallite size, and grain boundaries of the samples, as well as oxygen and/or water molecule chemisorbing on the surface. Obviously, the Al-doping effect causing the carrier concentration increasement is the main factor affecting conductivity with very little change in other conditions. It is worth noting 


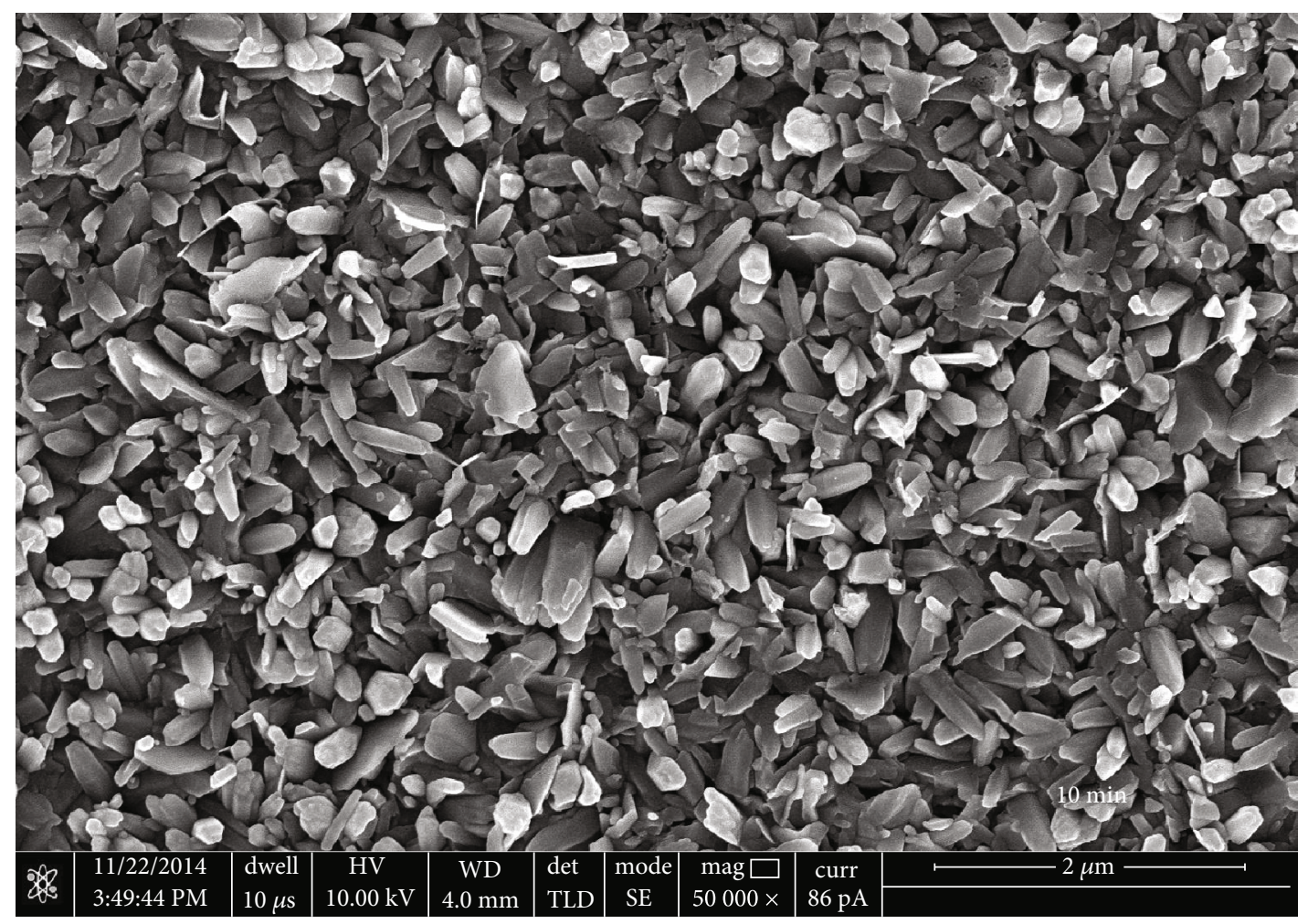

(a)

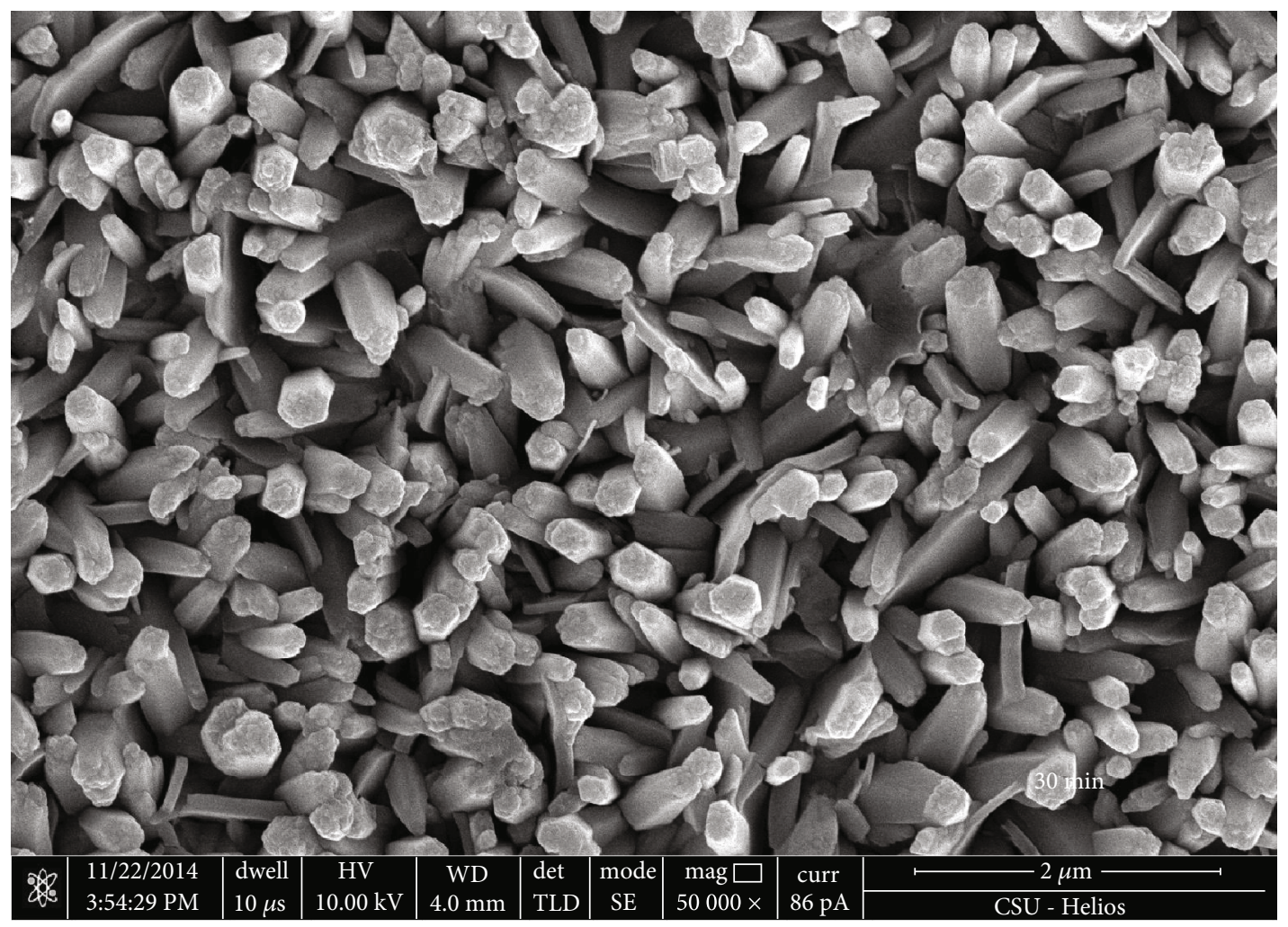

(b)

Figure 7: Continued. 


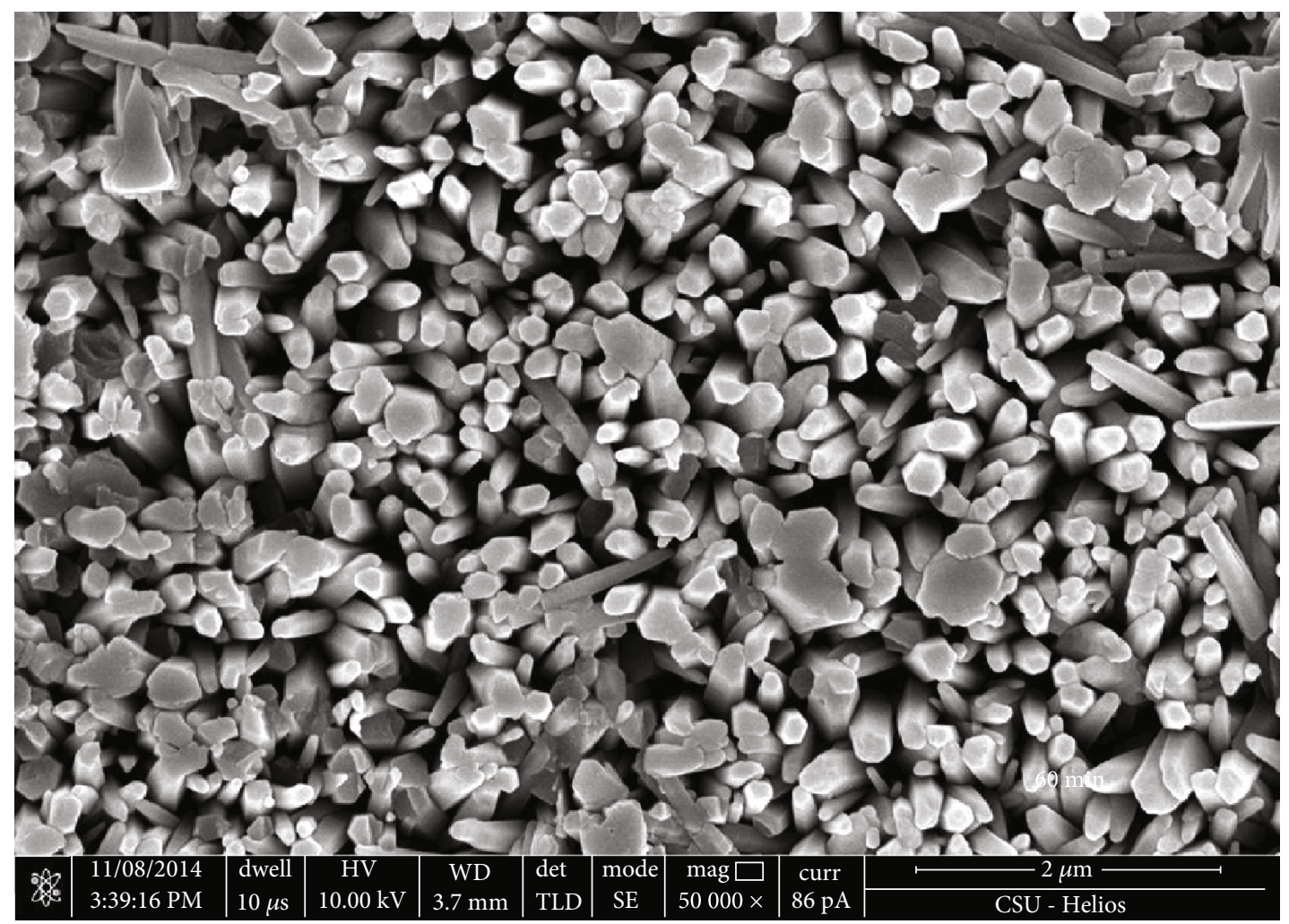

(c)

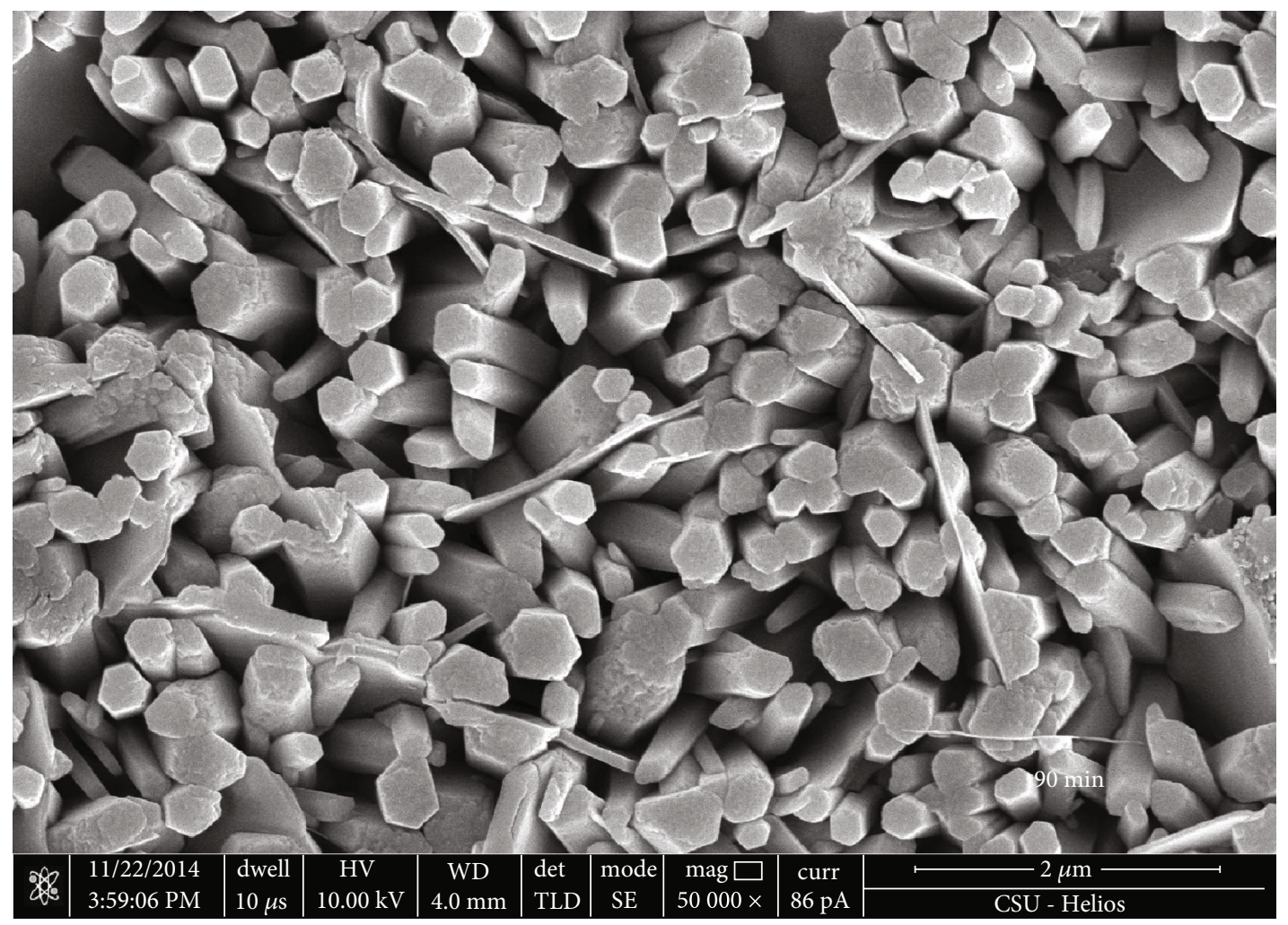

(d)

Figure 7: Morphological evolution of Al-doped $\mathrm{ZnO}$ NRAs grown by electrodeposition method as a function of deposition time. The deposition parameters: $3 \mathrm{mM} \mathrm{Zn}\left(\mathrm{NO}_{3}\right)_{2}, \mathrm{Al}^{3+} / \mathrm{Zn}^{2+}$ ratio 1 at $\%, 80^{\circ} \mathrm{C}$, electrode distance $2 \mathrm{~cm}$, applied potential $-1.5 \mathrm{~V}$, deposition time: (a) $10 \mathrm{~min}$, (b) $30 \mathrm{~min}$, (c) $60 \mathrm{~min}$, and (d) $90 \mathrm{~min}$. 


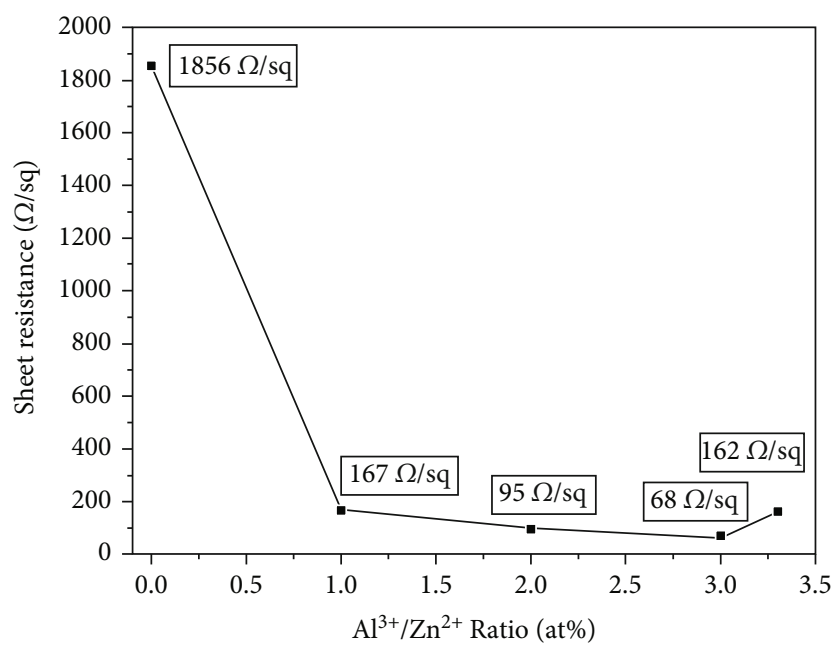

FIGURE 8: Sheet resistance of pure and $\mathrm{Al}$-doped $\mathrm{ZnO}$ samples as a function of $\mathrm{Al}^{3+} / \mathrm{Zn}^{2+}$ ratio in the precursors.

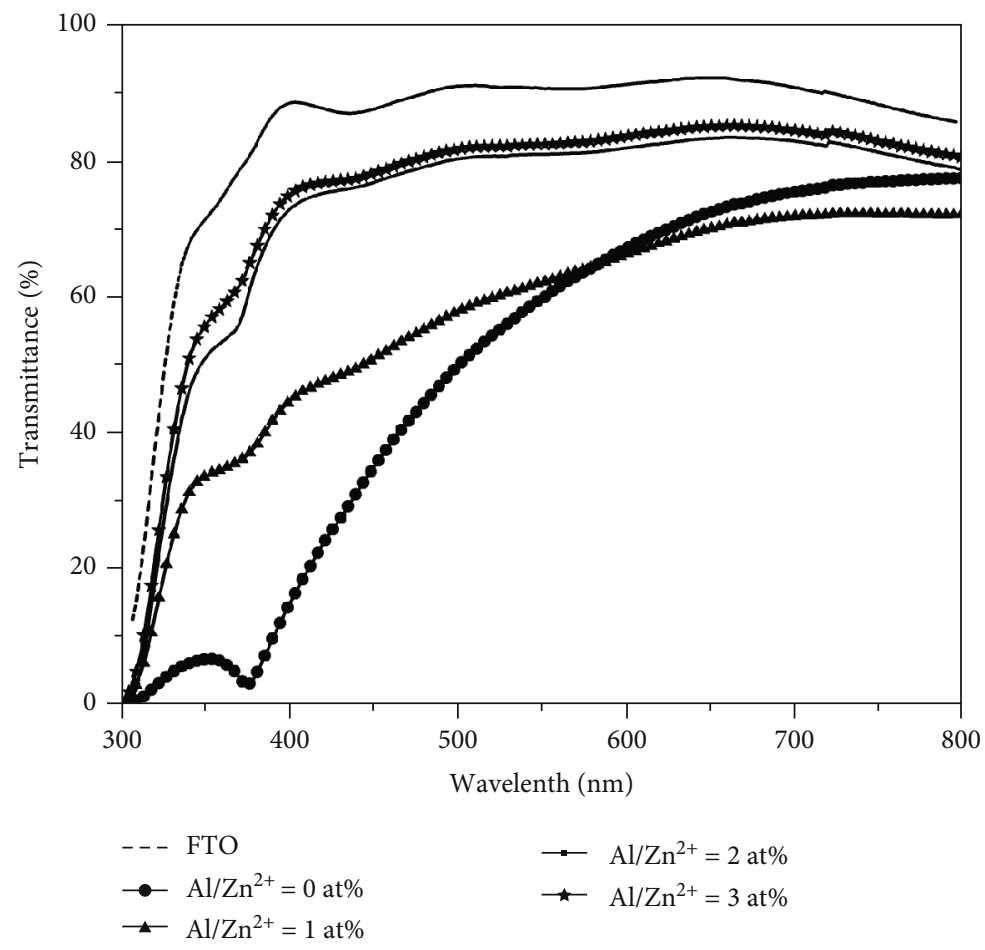

FIgure 9: Optical transmittance in the visible light wavelength from $300 \mathrm{~nm}$ to $800 \mathrm{~nm}$ of the FTO glass substrate and the electrodeposited $\mathrm{ZnO}$ samples with $\mathrm{Al}^{3+} / \mathrm{Zn}^{2+}$ ratio of $0,1,2$, and 3 at $\%$ in the precursors and deposition time of $30 \mathrm{~min}$.

whether the deposited $\mathrm{Al}^{3+}$ ions existed in the form of $\mathrm{Al}_{2} \mathrm{O}_{3}$ or are doped into $\mathrm{ZnO}$ lattice, or both? It is possible that some amorphous $\mathrm{Al}_{2} \mathrm{O}_{3}$ phase formed in the grain boundaries when the $\mathrm{Al}^{2+} / \mathrm{Zn}^{2+}$ ratio increased up to 2 at $\%$ although the X-ray results have not detected it in our samples. The growth conditions are vital for the $\mathrm{Al}^{3+}$ ion existing state. Many research groups have got similar results, for example, Liang et al. [47] successfully fabricated high crystalline Sb-doped $\mathrm{ZnO}$ NRAs with p-type conductivity, and Aragonès et al. [50] electrodeposited Al-doped $\mathrm{ZnO}$ films with different doping contents using the electrodeposition method. However, Zhu and coworkers [51] have investigated the growth of $\mathrm{ZnO}$ NRAs by hydrothermal process from aqueous solution composed of $25 \mathrm{mM}$ zinc nitrate and $25 \mathrm{mM}$ hexamethylenetetramine containing different concentration $(0,0.25,0.5$, and $1 \mathrm{mM})$ aluminium nitrate, and they speculated that $\mathrm{Al}$ atoms had not been doped into $\mathrm{ZnO}$ lattice. Compared with the electrodeposition process, the hydrothermal growth process may proceed in a relatively more equilibrium environment without applied potential, which may be the cause that $\mathrm{Al}$ atoms were unsuccessfully doped into $\mathrm{ZnO}$ lattice. 


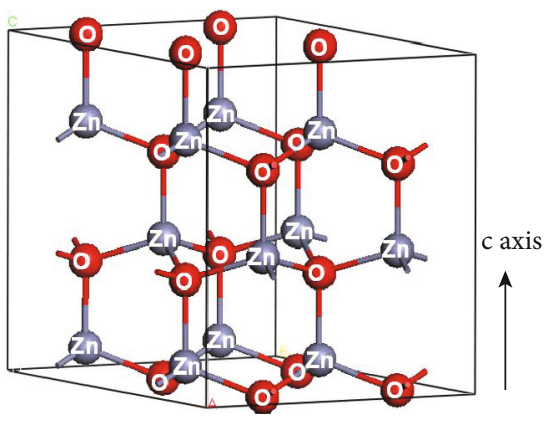

(a) Hexagonal crystal structure of $\mathrm{ZnO}$

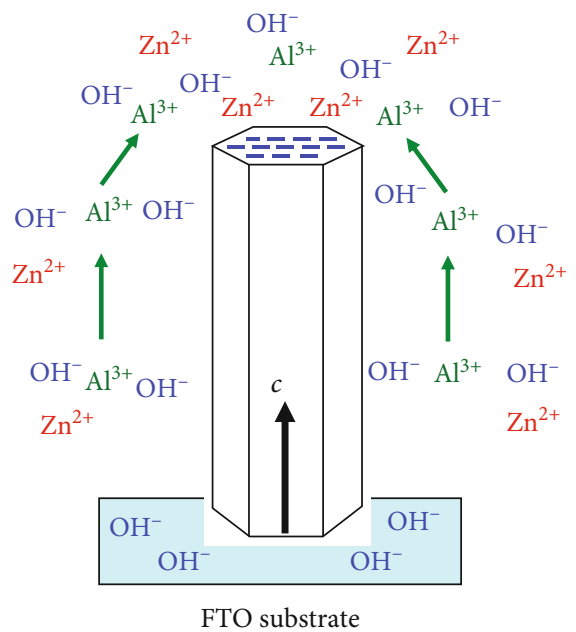

(b) Low $\mathrm{Al} 3+/ \mathrm{Zn} 2+$ ratio

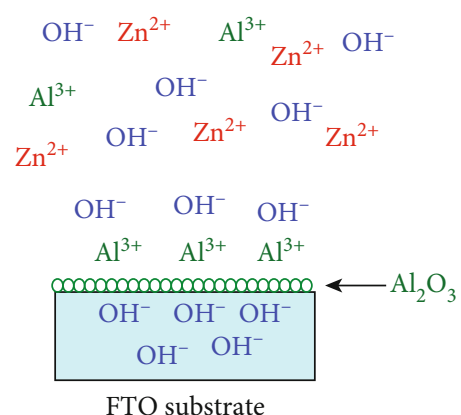

(c) High $\mathrm{Al} 3+/ \mathrm{Zn} 2+$ ratio

FIGURE 10: Schematic diagram of growth principle of $\mathrm{ZnO}$ nanorods on FTO substrates by electrodeposition method with different $\mathrm{Al}^{3+} / \mathrm{Zn}^{2+}$ ratio.

The average transmittance in the visible light wavelength from $400 \mathrm{~nm}$ to $700 \mathrm{~nm}$ of the FTO glass substrate and the electrodeposited $\mathrm{ZnO}$ samples with $\mathrm{Al}^{3+} / \mathrm{Zn}^{2+}$ ratio of 0,1 , 2 , and 3 at $\%$ in the precursors and deposition time of $30 \mathrm{~min}$ is $91 \%, 55 \%, 61 \%, 81 \%$, and $82 \%$, respectively, as shown in Figure 9. It is obviously seen that the average transmittance of Al-doped $\mathrm{ZnO}$ samples is largely higher than that of pure $\mathrm{ZnO}$ sample. The average transmittance of 2 at $\%$ and 3 at $\%$ Al-doped $\mathrm{ZnO}$ samples is very close, while with the $\mathrm{Al}$ doping content reducing to 1 at $\%$, the average transmittance of $\mathrm{Al}$-doped $\mathrm{ZnO}$ sample decreases to $61 \%$. Considering the light-trapping effect of the nanorod arrays, the relatively low transmittance above $60 \%$ of Al-doping $\mathrm{ZnO}$ NRAs for transparent electrodes of thin-film solar cells is reasonable. In our other present work, the solar cells based on pure ZnO-NRAs have obtained the best photovoltaic conversion efficiency with a deposition time of $30 \mathrm{~min}$ [40, 41], which further confirms the appropriate deposition time for the $\mathrm{ZnO}$ NRAs is about $30 \mathrm{~min}$.

3.5. Growth Principle of Electrodepositing Al-Doped $\mathrm{ZnO}$ Nanorods. Based on the characteristic and experiment data discussed above, the growth principle of Al-doped $\mathrm{ZnO}$ nanorods is proposed. The hexagonal wurtzite $\mathrm{ZnO}$ crystals can be considered as a number of alternating planes composed of four-fold coordinated $\mathrm{O}^{2-}$ and $\mathrm{Zn}^{2+}$ ions stacked alternately along the c-axis in Figure 10(a). The top $\mathrm{Zn}$ terminated (002) plane is positively charged, and the anions from the solution may be absorbed on this polar phase; in the same way, the O-terminated plane is negatively charged and the cations may be absorbed, both resulting in the fast growth of along (002) direction [37, 38]. However, a certain amount of $\mathrm{Al}^{3+}$ ions existing in the solution will precipitate with $\mathrm{OH}^{-}$prior to $\mathrm{Zn}^{2+}$, since the solubility product of $\mathrm{Al}(\mathrm{OH})_{3}\left(K_{\mathrm{sp}}=4.57 \times 10^{-33}, 25^{\circ} \mathrm{C}\right)$ is remarkably smaller than that of $\mathrm{Zn}(\mathrm{OH})_{2}\left(K_{\mathrm{sp}}=2.09 \times 10^{-16}, 25^{\circ} \mathrm{C}\right)$ at the same temperature. As illustrated in Figure 10(b), with a relatively low $\mathrm{Al}^{3+} / \mathrm{Zn}^{2+}$ ratio in the precursor solution, $\mathrm{Zn}^{2+}$ ions with a certain amount of $\mathrm{Al}^{3+}$ ions will preferentially absorb on the (002) plane due to the attractive force between positive cations and negative $\mathrm{O}^{2-}$ ions, resulting in the preferred growth along the c-axis; with $\mathrm{Al}^{3+} / \mathrm{Zn}^{2+}$ ratio increasing, more $\mathrm{Al}^{3+}$ ions also absorb on other side planes, which will inhibit $\mathrm{Zn}^{2+}$ ions from absorbing on these planes, leading to a higher aspect ratio of $\mathrm{ZnO}$ nanorods. In contrast, with a high $\mathrm{Al}^{3+} /$ $\mathrm{Zn}^{2+}$ ratio, more $\mathrm{Al}^{3+}$ ions will absorb on the (002) plane and other planes or even on the FTO substrates. However, the product of $\mathrm{Al}_{2} \mathrm{O}_{3}$ belongs to the insulator, which will prevent the electrochemical reaction from going on [49], as shown in Figure 10(c). Hence, the deposited products will grow into a mixture of nanosheets and nanorods or the electrodeposition process will stop due to the insulating $\mathrm{Al}_{2} \mathrm{O}_{3}$ layer on the FTO substrates. The result is consistent with the literature [49], which showed that for $\mathrm{Al}^{3+}$ concentrations up to $0.3 \mathrm{mM}$ in the electrochemical bath, a top layer of amorphous $\mathrm{Al}_{2} \mathrm{O}_{3}$ compound was obtained. Therefore, taking into account of desired morphology and phase purity, as well as good electrical conductivity and optical transmittance, the optimal window of $\mathrm{Al}^{3+} / \mathrm{Zn}^{2+}$ ratio in the precursors is determined at between 1 at $\%$ and 2 at $\%$ with applied potential of $-1.5 \mathrm{~V}$, bath temperature of $80^{\circ} \mathrm{C}$, and deposition time of about $30 \mathrm{~min}$.

\section{Conclusions}

In summary, $\mathrm{Al}$-doped $\mathrm{ZnO}$ NRAs have been grown via electrodeposition method from low concentration zinc nitrate aqueous solutions containing a small amount of aluminium nitrate without other auxiliary reagents at a highly negative applied potential. The results showed that $\mathrm{Al}$ atoms were successfully doped into $\mathrm{ZnO}$ crystal lattice, and the morphologies could be controlled by adjusting the $\mathrm{Al}^{3+} / \mathrm{Zn}^{2+}$ ratio in the precursors. The deposited Al-doped $\mathrm{ZnO}$ films grew into well-aligned hexagonal NRAs with the c-axis perpendicular to the substrates and then transited into a 
mixture of nanosheets and nanorods with $\mathrm{Al}^{3+} / \mathrm{Zn}^{2+}$ ratio increasing or the electrodeposition process will stop due to the insulating $\mathrm{Al}_{2} \mathrm{O}_{3}$ layer on the FTO substrates. They exhibited good electrical conductivity with sheet resistance of 68-167 $\Omega /$ square and appropriate visible light transmittance of $61-82 \%$. The optimal window of $\mathrm{Al}^{3+} / \mathrm{Zn}^{2+}$ ratio in the precursors is determined between 1 at $\%$ and 2 at $\%$ with applied potential of $-1.5 \mathrm{~V}$, bath temperature of $80^{\circ} \mathrm{C}$, and deposition time of about $30 \mathrm{~min}$. The self-assembling method provides a facile and efficient route for obtaining large-area textured transparent conductive $\mathrm{Al}$-doped $\mathrm{ZnO}$ NRAs at low cost, which have potential application in transparent electrodes of thin-film solar cells with light trapping.

\section{Data Availability}

The CV, XRD, SEM, TEM, XPS, and EDX data used to support the findings of this study are included within the article.

\section{Conflicts of Interest}

The authors declare that there is no conflict of interest regarding the publication of this paper.

\section{Acknowledgments}

This research was funded by the Natural Science Foundation of China, grant number [51172031], and the Natural Science Foundation of Hunan Province, grant number [2020JJ4097].

\section{References}

[1] Y. F. Hu, Y. L. Chang, P. Fei, R. L. Snyder, and Z. L. Wang, "Designing the electric transport characteristics of $\mathrm{ZnO}$ micro/nanowire devices by coupling piezoelectric and photoexcitation Effects," ACS Nano, vol. 4, no. 2, pp. 1234-1240, 2010.

[2] Z. R. Tian, J. A. Voigt, J. Liu et al., "Complex and oriented $\mathrm{ZnO}$ nanostructures," Nature Materials, vol. 2, no. 12, pp. 821-826, 2003.

[3] L. Gong, J. G. Lu, and Z. Z. Ye, "Transparent conductive Gadoped $\mathrm{ZnO} / \mathrm{Cu}$ multilayers prepared on polymer substrates at room temperature," Solar Energy Materials \& Solar Cells, vol. 95, no. 7, pp. 1826-1830, 2011.

[4] Z. L. Wang and J. H. Song, "Piezoelectric nanogenerators based on zinc oxide nanowire arrays," Science, vol. 312, no. 5771, pp. 242-246, 2006.

[5] D. Tamvakos, S. Lepadatu, V. A. Antohe et al., "Piezoelectric properties of template-free electrochemically grown $\mathrm{ZnO}$ nanorod arrays," Applied Surface Science, vol. 356, pp. 12141220, 2015.

[6] P. S. Shewale and Y. S. Yu, "Structural, surface morphological and UV photodetection properties of pulsed laser deposited Mg-doped $\mathrm{ZnO}$ nanorods: effect of growth time," Journal of Alloys and Compounds, vol. 654, no. 5, pp. 79-86, 2016.

[7] J. J. Li, L. T. Zhang, J. B. Zhu, Y. Liu, and W. C. Hao, “Aligned ZnO:Co nanorod arrays: Electrophoretic deposition fabrication and magnetic manipulation," Ceramics International, vol. 41, no. 3, pp. 3456-3460, 2015.

[8] S. Öztürk, A. Kösemen, Z. A. Kösemen, N. Kilinc, Z. Z. Öztürk, and M. Penza, "Electrochemically growth of Pd doped $\mathrm{ZnO}$ nanorods on QCM for room temperature VOC sensors," Sensors and Actuators B: Chemical, vol. 222, pp. 280-289, 2016.

[9] C. W. Zou, F. Liang, and S. W. Xue, "Synthesis and oxygen vacancy related $\mathrm{NO}_{2}$ gas sensing properties of $\mathrm{ZnO}$ :Co nanorods arrays gown by a hydrothermal method," Applied Surface Science, vol. 353, pp. 1061-1069, 2015.

[10] M. Law, L. Greene, J. C. Johnson, R. Saykally, and P. D. Yang, "Nanowire dye-sensitized solar cells," Nature Materials, vol. 4, no. 6, pp. 455-459, 2005.

[11] L. Li, T. Y. Zhai, Y. Bando, and D. Golberg, "Recent progress of one-dimensional $\mathrm{ZnO}$ nanostructured solar cells," Nano Energy, vol. 1, no. 1, pp. 91-106, 2012.

[12] J. J. Wu, W. P. Liao, and M. Yoshimura, "Soft processing of hierarchical oxide nanostructures for dye-sensitized solar cell applications," Nano Energy, vol. 2, no. 6, pp. 1354-1372, 2013.

[13] H. Lu, X. Y. Zhai, W. W. Liu, M. Zhang, and M. Guo, "Electrodeposition of hierarchical $\mathrm{ZnO}$ nanorod arrays on flexible stainless steel mesh for dye-sensitized solar cell," Thin Solid Films, vol. 586, pp. 46-53, 2015.

[14] X. Fang, Y. Li, S. Zhang, L. Bai, N. Y. Yuan, and J. N. Ding, "The dye adsorption optimization of $\mathrm{ZnO}$ nanorod-based dyesensitized solar cells," Solar Energy, vol. 105, pp. 14-19, 2014.

[15] Y. M. Sung, F. C. Hsu, and Y. F. Chen, "Improved charge transport in inverted polymer solar cells using surface engineered $\mathrm{ZnO}$-nanorod array as an electron transport layer," Solar Energy Materials \& Solar Cells, vol. 125, pp. 239-247, 2014.

[16] H. Woo Choi, K. S. Lee, N. David Theodore, and T. L. Alford, "Improved performance of $\mathrm{ZnO}$ nanostructured bulk heterojunction organic solar cells with nanowire-density modified by yttrium chloride introduction into solution," Solar Energy Materials \& Solar Cells, vol. 117, pp. 273-278, 2013.

[17] L. Pan, S. B. Wang, W. B. Mi et al., "Undoped $\mathrm{ZnO}$ abundant with metal vacancies," Nano Energy, vol. 9, pp. 71-79, 2014.

[18] H. Lu, M. Zhang, and M. Guo, "Controllable electrodeposition of $\mathrm{ZnO}$ nanorod arrays on flexible stainless steel mesh substrate for photocatalytic degradation of Rhodamine B," Applied Surface Science, vol. 317, pp. 672-681, 2014.

[19] Y. J. Liu, D. Huang, H. X. Liu, T. D. Li, and J. G. Wang, “ZnO tetrakaidecahedrons with co-exposed $\{001\},\{101\}$, and $\{100\}$ facets: shape-selective synthesis and enhancing photocatalytic performance," Crystal Growth \& Design, vol. 19, no. 5, pp. 2758-2764, 2019.

[20] Z. M. Bai, X. Q. Yan, Z. Kang, Y. P. Hu, X. H. Zhang, and Y. Zhang, "Photoelectrochemical performance enhancement of $\mathrm{ZnO}$ photoanodes from $\mathrm{ZnIn}_{2} \mathrm{~S}_{4}$ nanosheets coating," Nano Energy, vol. 14, pp. 392-400, 2015.

[21] R. Lv, T. Wang, F. L. Su, P. Zhang, C. J. Li, and J. L. Gong, "Facile synthesis of $\mathrm{ZnO}$ nanopencil arrays for photoelectrochemical water splitting," Nano Energy, vol. 7, pp. 143-150, 2014.

[22] Y. J. Liu, H. X. Liu, H. M. Zhou, T. D. Li, and L. N. Zhang, "A Z-scheme mechanism of $\mathrm{N}-\mathrm{ZnO} / \mathrm{g}-\mathrm{C}_{3} \mathrm{~N}_{4}$ for enhanced $\mathrm{H}_{2}$ evolution and photocatalytic degradation," Applied Surface Science, vol. 466, pp. 133-140, 2019.

[23] H. F. Zhai, J. J. Qi, Y. Tan et al., "Construction of $1 \mathrm{D}-\mathrm{MoS}_{2}$ nanorods/ $\mathrm{LiNb}_{3} \mathrm{O}_{8}$ heterostructure for enhanced hydrogen evolution," Applied Materials Today, vol. 18, article 100536, 2020.

[24] X. Y. Yang, H. X. Liu, T. D. Li et al., "Preparation of flower-like [email protected] core-shell structure enhances photocatalytic 
hydrogen production," International Journal of Hydrogen Energy, vol. 45, no. 51, pp. 26967-26978, 2020.

[25] M. Li, X. Qian, A. D. Li, Y. Q. Cao, H. F. Zhai, and D. Wu, “A comparative study of growth and properties of atomic layer deposited transparent conductive oxide of $\mathrm{Al}$ doped $\mathrm{ZnO}$ films from different Al precursors," Thin Solid Films, vol. 646, pp. 126-131, 2018.

[26] H. F. Zhai, B. Y. Xia, and H. S. Park, "Ti-based electrode materials for electrochemical sodium ion storage and removal," Journal of Materials Chemistry A, vol. 7, no. 39, pp. 2216322188, 2019.

[27] Z. N. Jia, X. D. Zhang, Y. Liu, J. Ma, C. C. Liu, and Y. Zhao, "Conductive white back reflector and scatter based on $\mathrm{ZnO}$ nanostructure arrays for harvesting solar energy," Nano Energy, vol. 1, no. 6, pp. 783-788, 2012.

[28] O. Lupan, V. M. Guérin, I. M. Tiginyanu et al., "Well-aligned arrays of vertically oriented $\mathrm{ZnO}$ nanowires electrodeposited on ITO-coated glass and their integration in dye sensitized solar cells," Journal of Photochemistry and Photobiology A: Chemistry, vol. 211, no. 1, pp. 65-73, 2010.

[29] T. Pauporte, G. Bataille, L. Joulaud, and F. J. Vermersch, "Well-aligned $\mathrm{ZnO}$ nanowire arrays prepared by seed-layerfree electrodeposition and their Cassie-Wenzel transition after hydrophobization," The Journal of Physical Chemistry, vol. 114, no. 1, pp. 194-202, 2009.

[30] T. Özdal, R. Taktakoğlu, H. Özdamar, M. Esen, D. K. Takçı, and H. Kavak, "Crystallinity improvement of $\mathrm{ZnO}$ nanorods by optimization of low-cost electrodeposition technique," Thin Solid Films, vol. 592, pp. 143-149, 2015.

[31] H. Lu, F. Zheng, M. Zhang, and M. Guo, "Effects of preparing conditions on controllable one-step electrodeposition of $\mathrm{ZnO}$ nanotube arrays," Electrochimica Acta, vol. 132, pp. 370-376, 2014.

[32] N. Kitazawa, M. Aono, and Y. Watanabe, "Growth of vertically aligned one-dimensional $\mathrm{ZnO}$ nanowire arrays on sol-gel derived $\mathrm{ZnO}$ thin films," Journal of Physics and Chemistry of Solids, vol. 75, no. 11, pp. 1194-1200, 2014.

[33] M. Skompska and K. Zarębska, "Electrodeposition of $\mathrm{ZnO}$ nanorod arrays on transparent conducting substrates-a review," Electrochimica Acta, vol. 127, pp. 467-488, 2014.

[34] A. S. Kamble, B. B. Sinha, K. Chung et al., "Effect of hydroxide anion generating agents on growth and properties of $\mathrm{ZnO}$ nanorod arrays," Electrochimica Acta, vol. 149, pp. 386-393, 2014.

[35] R.-E. Nowak, M. Vehse, O. Sergeev, K. von Maydell, and C. Agert, " $\mathrm{ZnO}$ nanorod arrays as light trapping structures in amorphous silicon thin-film solar cells," Solar Energy Materials and Solar Cells, vol. 125, no. 125, pp. 305-309, 2014.

[36] A. Q. Bai, Y. Tang, and J. Chen, "Efficient photon capturing in $\mathrm{Cu}(\mathrm{In}, \mathrm{Ga}) \mathrm{Se}_{2}$ thin film solar cells with $\mathrm{ZnO}$ nanorod arrays as an antireflective coating," Chemical Physics Letters, vol. 636, pp. 134-140, 2015.

[37] F. Anwar, R. Mahbub, S. S. Satter, and S. M. Ullah, "Effect of different HTM layers and electrical parameters on $\mathrm{ZnO}$ nanorod-based lead-free perovskite solar cell for highefficiency performance," International Journal of Photoenergy, vol. 2017, Article ID 9846310, 9 pages, 2017.

[38] P. Wang, J. Zhao, J. Liu et al., "Stabilization of organometal halide perovskite films by $\mathrm{SnO}_{2}$ coating with inactive surface hydroxyl groups on $\mathrm{ZnO}$ nanorods," Journal of Power Sources, vol. 339, pp. 51-60, 2017.
[39] S. Li, P. Zhang, Y. Wang et al., "Interface engineering of high efficiency perovskite solar cells based on $\mathrm{ZnO}$ nanorods using atomic layer deposition," Nano Research, vol. 10, no. 3, pp. 1092-1103, 2017.

[40] Z. Y. Peng, Z. Liu, J. L. Chen et al., "Influence of $\mathrm{ZnO}$ nanoarray interlayer on the charge transfer performance of quantum dot sensitized solar cells," Electrochimica Acta, vol. 299, pp. 206-212, 2019.

[41] W. Li, Z. Y. Peng, Z. Sun et al., "Orientation modulation of $\mathrm{ZnO}$ nanorods on charge transfer performance enhancement for $\mathrm{Sb}_{2} \mathrm{~S}_{3}$ quantum dot sensitized solar cells," Journal of Alloys and Compounds, vol. 816, article 152628, 2020.

[42] Y. Zhang, G. Zhai, L. Gao et al., "Improving performance of perovskite solar cells based on $\mathrm{ZnO}$ nanorods via rod- length control and sulfidation treatment," Materials Science in Semiconductor Processing, vol. 117, article 105205, 2020.

[43] D. Commandeur, H. Morrissey, and Q. Chen, "Solar cells with high short circuit currents based on CsPbBr3PerovskiteModified ZnO nanorod composites," ACS Applied Nano Materials, vol. 3, no. 6, pp. 5676-5686, 2020.

[44] P. S. Chandrasekhar, A. Dubey, and Q. Qiao, "High efficiency perovskite solar cells using nitrogen-doped graphene/ZnO nanorod composite as an electron transport layer," Solar Energy, vol. 197, pp. 78-83, 2020.

[45] M. R. Khajavi, D. J. Blackwood, G. Cabanero, and R. TenaZaera, "New insight into growth mechanism of $\mathrm{ZnO}$ nanowires electrodeposited from nitrate-based solutions," Electrochimica Acta, vol. 69, pp. 181-189, 2012.

[46] M. Kemell, F. Dartigues, M. Ritala, and M. Leskela, "Electrochemical preparation of In and $\mathrm{Al}$ doped $\mathrm{ZnO}$ thin films for $\mathrm{CuInSe}_{2}$ solar cells," Thin Solid Films, vol. 434, no. 1-2, pp. 20-23, 2003.

[47] J. K. Liang, H. L. Su, C. L. Kuo et al., "Structural, optical and electrical properties of electrodeposited Sb-doped $\mathrm{ZnO}$ nanorod arrays," Electrochimica Acta, vol. 125, pp. 124-132, 2014.

[48] H. M. Zhou, D. Q. Yi, Z. M. Yu, L. R. Xiao, and J. Li, "Preparation of aluminum doped zinc oxide films and the study of their microstructure, electrical and optical properties," Thin Solid Films, vol. 515, no. 17, pp. 6909-6914, 2007.

[49] J. L. Chen, J. Chen, D. Chen et al., "Electrochemical deposition of $\mathrm{Al}$-doped $\mathrm{ZnO}$ transparent conducting nanowire arrays for thin-film solar cell electrodes," Materials Letters, vol. 117, pp. 162-164, 2014.

[50] A. C. Aragonès, A. Palacios-Padrós, F. Caballero-Briones, and F. Sanz, "Study and improvement of aluminium doped $\mathrm{ZnO}$ thin films: limits and advantages," Electrochimica Acta, vol. 109, pp. 117-124, 2013.

[51] S. B. Zhu, X. Tian, L. M. Shan et al., "Effect of $\mathrm{Al}^{3+}$ on the growth of $\mathrm{ZnO}$ nanograss film and its application in dyesensitized solar cells," Ceramics International, vol. 39, no. 8, pp. 9637-9644, 2013. 